\title{
Evaluation of the Blended Learning approach to Teaching Software Engineering
}

\author{
Joseph Kizito Bada ${ }^{1}$
}

(C) Uganda Martyrs University

\begin{abstract}
This research presents experimentation of MOODLE course management system for teaching software engineering and process modelling to master's degree students. The students used MOOLE for online discussions, assignments and for downloading lecture notes for a duration of four months. Thereafter, they evaluated the learning environment with questionnaires. The results indicate that MOODLE is a highly accepted learning management system for teaching and learning in a resource limited country. However, for a learning management system like MOODLE to be effectively implemented in a University setting, it is important for the University management to invest in the initial computer hardware equipment and Internet connectivity infrastructure to overcome technology barriers.
\end{abstract}

Keywords $\cdot$ MOODLE $\cdot$ Blended learning $\cdot$ E-learning

\section{Introduction}

In the contemporary educational advancements (Hirtz, 2008), learning management systems (LMS) have significant impact on many aspects of teaching and learning process. They provide web-based interfaces supporting a wide range of activities that include forums, contents, questionnaires, chats, assignments and other educational tools. These tools make it easy to implement pedagogical approaches of a constructivist nature, consisting of building of knowledge through the completion of various activities (Knuth and Cunningham, 1993; Jonassen, 1999; and Khalifa and Lam, 2002). These tools also promote collaborative learning (Tan et al, 2008), a good complement to constructivist teaching.

Moodle (Modular Object-Oriented Dynamic Learning Environment) is a popular learning management system (Moodle, 2009). It has 45,000 validated registered sites at the beginning of 2010, and it is widely used by Universities and higher educational institutions (Martin-Blas and Serrano-Fernandez). Another benefit of using Moodle is its availability as open-source software (Trenas et al., 2011).

\footnotetext{
${ }^{1}$ School of Computing, University of Eastern Finland. E-mail: jbada17@gmail.com
} 
In this research, Moodle learning management system was configured for teaching software engineering course to a class of 30 postgraduate students. This is the first time of using this learning management system in the University. This system has not been used for conducting any course at any faculty of the University. The success of this experiment brings new opportunity of starting online courses in the University.

\section{E-learning Definition}

There are a number of definitions of e-learning as a method of extending educational process through the use of ICT. E-learning is defined as "the use of new multimedia technologies and the Internet to improve the quality of learning by facilitation access to resources and services as well as remote exchanges and collaboration" (European Commission, 2011). E-learning as a form of education, exists at several levels: as a completely independent form, but also as an integral part of or an extension of "classical" education. ICT can serve as an aid to classical teaching, as a blended (hybrid, mixed mode) learning combining the classical teaching in classroom with teaching assisted by the technology, or completely as online learning where students learn independently, mostly over the Internet (World Wide Web) and without the need to be physically present within the learning environment (Bullen, et al, 2006).

\section{Theories of Learning}

Different theories of learning complement each other and may even overlap. Learning systems should comprise behaviourism, cognitivism and constructivism (Ally, et al, 2004). The behaviourist school observes how the behaviour of the instructor and other external factors affect learning. According to behaviourists, students need approval and support, which should be provided in the shortest time possible, and learning is an incremental rather than a single-step process. Learning is strengthened by repeated success. The cognitivist school perceives learning as a mental process. Learning is considered as an active process of transforming experience into organized concepts, with emphasis on individual differences in ability and motivation between students. The focus is on how individuals perceive, interpret, store and memorize information. The constructivist school recognizes learning as an active process of constructing meaning. Students do not memorize what was said by the instructor. The students construct their own versions of the learning content. Students should be helped to construct their own meaning of knowledge, to enable them reflect upon, discuss and exchange ideas among themselves and their instructors. High-quality learning environments in general, and high-quality online learning environments in particular, should be based on multiple theories of learning (Mishra, 2002; Johnson, et al, 2002). In the field of education today, constructivism is the most accepted model of learning (Morphew, 2000); this emphasizes the student-centred model, and active-learning. Learning is achieved when students are actively involved in the learning process and if this process is taking place in a collaborative learning environment (Bermejo, 2005).

\section{Blended Learning}

Blended learning is the learning based on various combinations of classical face-to-face lectures, learning over the Internet, and learning with support of other technologies such as online and traditional learning environments, technology and media for learning content 
delivery, different teaching and learning methods, group and individual learning activities, and synchronous and asynchronous interactions. The aim of having multiples approaches to learning is to motivate students and assist them in successfully mastering the course (Alanso F, 2005; Thorne, 2003; Bersin, 2004).

\section{Benefits of E-learning to Students and Institutions}

Reduced overall cost is the most important factor in adopting e-learning. The e-learning eliminates costs associated with classroom rentals, student travel, lodging, and meals. The reduction of time spent away from the job by employees may be the most positive offshoot. Learning times reduced an average of 40 to 60 percent (Brandol, 1997). Increased retention and application to the job averages an increase of 25 percent over traditional methods (Fletcher, 1991). Consistent delivery of content is possible with asynchronous, self-paced e-learning. Expert knowledge is communicated, but more importantly captured, with good e-learning and knowledge management systems. Proof of completion and certification, essential elements of training initiatives, can be automated.

Along with increased retention, reduced learning time, other advantages of e-learning to a student include: on-demand availability where the student is free to do the training at his or her convenient time; self-spacing for slow and fast learners reduces stress and increases satisfaction; and confidence that the reference materials are available online reduces burden of responsibility of mastery.

\section{Challenges Facing E-Learning approach to Education}

New challenge facing designers and human computer interaction researchers is to develop software tools and applications that are effective for e-learning. Evaluators do not have the knowledge, instruments and/or time available to handle usability (Tanja et al., 2007).

The following critical factors have failed e-learning projects: initial design problems; emphasis on technology and little attention to instruction design aspect of e-learning; lack of understanding of e-learning tasks; interactivity and user friendliness of e-learning platforms are not adequately addressed; and problems with development process, distribution and maintainability of e-learning courses and platforms (Romiszowski, 2004). E-learning problems students are likely to come across in a tertiary institution setting include: inaccessibility due to lack of personal Internet connectivity; lack of support from peer group in learning process due to absence of collaboration and problem-solving; reduced student-teacher relationship which can create difficulty for slow learners who need support of the instructors from time to time; accessibility/usability problem; and additional costs from printing and Internet payment for the case of an e-learning student (Nikolakaki and Paraskeva, 2005).

\section{Learning Management System (LMS)}

Technology is the focal point in an online environment. Learning Management System (LMS) is the basis for all interactions in an online system. Considering technology as the central theme in an education systems raises so many questions about other important aspects of learning such as pedagogy. Technological considerations shouldn't undermine the needs of the learner and the learning processes, but that to focus on technology and to study the ways in which technology can shape interaction among learners-teacher-content 
helps us to understand how technology-mediated interaction influences social presence, structure, learner control, and feedback. Technology should not be studied separately or as a "mere vehicle" (Vrasidas, 2004).

Researchers, educators, and computer scientists need to work together in examining the ways that technologies can facilitate teaching and learning and conducting research that can point the way for improving the development of such technologies. Typical questions that can be asked and addressed, as e-learning systems are developed, include the following: how do technology affordances permit and constrain certain kinds of interactions? How does technology-mediated interaction shape structure, learning, learner control, and social presence?, what technologies can be used to undertake the kinds of tasks that learners and teachers cannot easily perform (e.g., store and retrieve information, execute advanced calculations) and allocate learners and teachers the tasks they do best (e.g. use of Intelligent Agents)? , how has technology made some content obsolete and other content more important than ever? What content should be relegated to a Learning Management instead of the teacher and students? What combination of technologies, content, context, and instructional methods are appropriate for what kinds of instructional goals, teachers, and learners? (Vrasidas, 2002).

The following specific duties and tasks of the teacher as designer: designing the overall structure of the course, the syllabus, and establishing expectations for successful course completion; selecting the activities that students will be asked to engage in while taking the online course; when is it appropriate using individual assignments, collaborative groups, online discussions and debates, etc.? ; Selecting the learning strategies and appropriate media that benefits students in achieving the desired outcomes. For example, deciding when to use a visual illustration, a video clip, an audio strip, or an animation, and how it is supporting learning (Vrasidas, 2004).

A Learning Management System should provide tools that enable students and teachers to seamlessly integrate real-world authentic activities within class schedule; social and collaborative: learning is a social activity and students learn best when they interact frequently with teachers and peers. A Learning Management System should allow learners to interact by providing synchronous and asynchronous communication tools; reflective: learners engage in reflective thinking about their actions, skills, competencies, knowledge, and meta-learning skills. A Learning Management System should provide tools that scaffold and support reflection on the learning process e.g. journal keeping, probing questions to reflect on, etc.; requires prompt feedback. Integrate feedback within the grade book. A Learning Management System can use Intelligent Agents to provide feedback to student work and help the teacher monitor student progress (Vrasidas, 2000).

\section{Methodology}

The author configured the Moodle learning management system to provide an online platform for teaching software engineering and process modelling course to a group of 30 students offering MSc in computer science and Information systems. The Moodle learning environment is quite easy to configure and students learn to use it within short time without getting much difficulties. Figure 1 shows the online class in Moodle engaging in an online discussion forum. This e-learning platform supported students in a number of ways including: flexibility in submission of assignments, knowledge sharing through 
discussion forum, accessing the learning material from online at any time and seeking advice from the course instructor and class members at any time.

\begin{tabular}{|c|c|c|c|}
\hline \multirow{2}{*}{\multicolumn{4}{|c|}{ 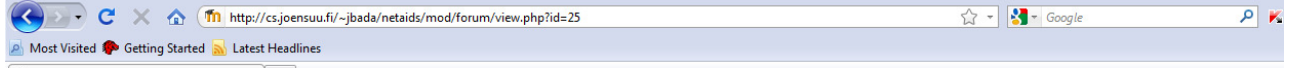 }} \\
\hline & & & \\
\hline \multicolumn{4}{|l|}{ Tn SE \& PM: Contribution of Software E... $\div$} \\
\hline Software Engineering & Erusah Makubuya & 1 & $\begin{array}{l}\text { Peter Yig } \\
\text { Thu, } 31 \text { Mar } 2011,01: 13 \mathrm{AI}\end{array}$ \\
\hline Content Management System & Joshua Wandera & 2 & $\begin{array}{l}\text { Joshuu Wander } \\
\text { Mon, } 28 \text { Mar } 2011,12: 17 \text { PI }\end{array}$ \\
\hline E-government & Erusah Makubuya & 1 & $\begin{array}{l}\text { Envsah Makubuy } \\
\text { Mon, } 28 \text { Mar } 2011,11: 35 \text { Al }\end{array}$ \\
\hline What are good candidate software development projects for the Waterfall Model? & R/Habiba Ngugi & 0 & $\begin{array}{l}\text { Habiba Noü } \\
\text { Mon, } 28 \text { Mar 2011, 10:48 Ail }\end{array}$ \\
\hline Local software for e-government & $2-$ Joseph Bada & 26 & 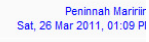 \\
\hline Rational of studying software engineering & - Vangi Mauka Muhindo & 0 & 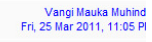 \\
\hline Gender and ICT Development & 2. Betty Ethel Naluyima & 2 & $\begin{array}{l}\text { Betty Ehel Nalyyim } \\
\text { Thu, } 24 \text { ara } 2011,07: 46 \text { PI }\end{array}$ \\
\hline Education & Humphrey Mukooyo & 0 & $\begin{array}{l}\text { Aumphrey Mukooy } \\
\text { Wed, } 23 \text { War } 2011,12: 13 \mathrm{PI} \\
\end{array}$ \\
\hline Non-internet e-government & Pontien Masengesho & 3 & 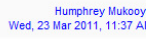 \\
\hline Software Engineering & Erusah Makubuya & 0 & 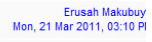 \\
\hline ELECTRONIC VOTING & 2. Fred Onen & 0 & Mon, 14 Mar 2011,03 Fred One \\
\hline Telemedicine & - Margret Masika & 1 & $\begin{array}{ll}\text { Joseph Bad } & \text { Bun, } 13 \text { Mar } 2011,09: 02 \mathrm{PI} \\
\end{array}$ \\
\hline Software Engineering e-government & Al Habiba Ngugi & 4 & Sun, 13 mar $2011,08.59$ Pl \\
\hline DATA LOST IN ACCESS & 2. Fred Onen & 2 & $\begin{array}{l}\text { Joseph Bad } \\
\text { Sun, } 13 \text { Mar } 2011,08: 53 \text { PI }\end{array}$ \\
\hline 甌 Define Engineering and Software Engineering. "Software is a layered technology"- Discuss & - Erick Kipkirui & 2 & $\begin{array}{l}\text { Joseph Bad } \\
\text { Sun, } 13 \text { Mar } 2011,08.50 \mathrm{PI}\end{array}$ \\
\hline
\end{tabular}

\section{Figựre 1: Online Class Discussion Forum}

The course ran for 4 months at the LMS site with address http://cs.joensuu.fi/ jbada/netaids. The students downloaded all the course material from the e-learning, all the assignment were done online either through discussion forum or individual submissions, assignment marks and grades were checked by individual students online, and individual students received messages for new postings of course materials and coursework marks through emails. The topics of the course are given in Table 1 and Table 2 gives sample questions for the coursework.

Table 1: Course Content

\section{Software Engineering topics}

1 Introduction to software engineering

2 Software development life cycle

3 Software requirements

4 Software development

4 methodologies

5 Software design

6 Program coding

7 Software testing

8 Systems implementation

9 Software quality

\section{Software process modelling}

1 UML diagrams

2 Use case modelling

3 Frameworks

\section{Software architecture}

Table 2: Sample coursework

Assignment questions
Software engineering practitioners can shape the
future of e-government of developing countries by
developing software applications relevant to the local
needs of these countries. Justify the above
statement with a relevant example giving clear
explanation of contribution software can make in
service delivery (10 marks). (Final date:
3/April/2011).
Compare the following software development
methodologies: Waterfall model, Prototyping, time-
boxing model and agile development methodologies
(Hint: show differences in terms of scope control,
schedule control, human resource needs, and
product quality). (10 marks) Submit your work online
by 3/5/2011


The students took an off line examination at the end of the semester. This end of semester examination accounted for $60 \%$ of the overall assessment. Questionnaires were administered to evaluate the Moodle environment students used for studying the course. The evaluation results are presented in the next section.

\section{Research Instrument}

We designed a questionnaire on a five-point Likert scale (1 indicating an extremely negative rating and 5 an extremely positive rating) to gather responses related to the items defined in Table 5. The questionnaire had items that measured the latent variables namely the computer games and the learning outcome. These latent variables were each measured using a set of theoretical constructs or manifest variables or indicators. The students completed the questionnaire and submitted it along with their written comments. Cronbach alpha was computed for each construct to identify whether the items belonged together within a construct. There are a number of opinions on acceptable levels of Cronbach alpha. For example, an alpha of 0.80 or higher may be considered, or a value of 0.7 or higher is also most commonly considered. For our research we expected the values of Cronbach alphas to be well above 0.70 . Table 3 below presents the alpha values of the variables.

Table 3: Cronbach's Alpha Coefficient for Items in the Instrument

\begin{tabular}{llll}
\hline Variable & Item & Code & Alpha \\
\hline Perceived & Learning to use MOODLE is easy for me & E1 & 0.728 \\
Ease of & I find it easy to download lecture handouts from MOODLE & E2 & 0.757 \\
Use (PEU) & I find MOODLE easy to use & E3 & 0.725 \\
& I find it easy to do assignments using MOODLE & E4 & 0.731 \\
& It is easy for me to build my skills in using MOODLE & E5 & 0.754 \\
Perceived & Using MOODLE would improve my skills in e-learning & E6 & 0.790 \\
Usefulness & Using MOODLE during my postgraduate studies would & E7 & 0.741 \\
(PU) & enable me to accomplish tasks quickly & E8 & 0.747 \\
& I find MOODLE useful in my studies & E9 & 0.733 \\
Attitude & Using MOODLE increases my effectiveness in the course \\
toward use & I look forward to those aspects of my course that require & E10 & 0.721 \\
(ATT) & MOODLE makes learning more interesting & E11 & 0.727 \\
& Learning with MOODLE is innovative approach to learning & E12 & 0.758 \\
Intention to & I will use MOODLE in the future & E13 & 0.725 \\
Use (INT) & I will continue to use MOODLE in the other course units & E14 & 0.730 \\
& I plan to use MOODLE in my own classes & E15 & 0.718 \\
\hline
\end{tabular}

Table 3 shows that Cronbach's alpha coefficient was found to be above 0.7 for all the items in the instrument.

\section{Findings}

Questionnaires were used to collect data from students related to their experience with Moodle learning management system. The questionnaires included closed-ended questions designed on a five-point Likert scale where 1 indicates complete (strong) disagreement to the statement and 5 shows complete agreement to a given statement. 30 
questionnaires were filled and collected. Cronbach's alpha coefficient, calculated statistically depending on the variance of each item, was found to be 0.764 .

As shown in Table 4, the mean value of the 15 -item form is 4.27 , which indicates acceptance of Moodle for teaching and learning software engineering and process modelling. The highest scores in the form were received by the following items: "I find it easy to download lecture handouts from Moodle (4.57)"; "Using Moodle increases my effectiveness in the course (4.47)"; "I will use Moodle in the future (4.40)"; "Using Moodle would improve my skills in e-learning (4.40)"; and "Using Moodle during my Postgraduate studies would enable me to accomplish tasks quickly (4.40"). From the above findings we affirm that:

- The students found it easy to learn and use MOODLE for downloading lecture notes and answering questions in assignments

- The students built their skills in e-learning at a faster rate using MOODLE and it enabled them to accomplish class tasks easily

- MOODLE e-learning environment offered new insight into learning process and students appreciate using this platform again in the future courses they take; some students also expressed the desire to use MOODLE for teaching in the future.

Table 4: Data Collection Form

\begin{tabular}{|c|c|c|c|c|c|c|c|c|c|c|c|}
\hline \multirow[t]{2}{*}{ Item } & \multirow{2}{*}{\multicolumn{2}{|c|}{ SD }} & \multirow{2}{*}{\multicolumn{2}{|c|}{ D }} & \multirow{2}{*}{\multicolumn{2}{|c|}{$\mathbf{U}$}} & \multicolumn{2}{|c|}{$A$} & \multicolumn{2}{|c|}{ SA } & \multirow{2}{*}{ Mean } \\
\hline & & & & & & $\%$ & $\mathrm{~F}$ & $\%$ & $\mathrm{~F}$ & $\%$ & \\
\hline $\begin{array}{l}\text { Learning to use Moodle is easy for } \\
\text { me }\end{array}$ & 1 & 3 & 0 & 0 & 3 & 10 & 15 & 50 & 11 & 37 & 4.2 \\
\hline $\begin{array}{l}\text { I find it easy to download lecture } \\
\text { handouts from Moodle }\end{array}$ & 0 & 0 & 0 & 0 & 2 & 7 & 9 & 30 & 19 & 63 & 4.57 \\
\hline I find Moodl & 0 & 0 & 1 & 3 & 3 & 10 & 18 & 60 & 8 & 27 & 4.1 \\
\hline $\begin{array}{l}\text { I find it easy to do assignments using } \\
\text { Moodle }\end{array}$ & 0 & 0 & 2 & 7 & 4 & 13 & 14 & 47 & 10 & 33 & 4.07 \\
\hline $\begin{array}{l}\text { It is easy for me to build my skills in } \\
\text { using Moodle }\end{array}$ & 0 & 0 & 2 & 7 & 1 & 3 & 16 & 53 & 11 & 37 & 4.2 \\
\hline would improve my & & 3 & 0 & 0 & 0 & 0 & 14 & 47 & 15 & 50 & 4.4 \\
\hline $\begin{array}{l}\text { ould enable } \\
\text { quickly }\end{array}$ & 0 & 0 & 0 & 0 & 0 & 0 & 18 & 60 & 12 & 40 & 4.4 \\
\hline I find & 0 & 0 & 0 & 0 & 3 & 10 & 18 & 60 & 9 & 30 & 4.2 \\
\hline $\begin{array}{l}\text { Using Moodle increases my } \\
\text { effectiveness in the course }\end{array}$ & c & 0 & 0 & 0 & 3 & 10 & 10 & 33 & 17 & 57 & 4.47 \\
\hline $\begin{array}{l}\text { I look forward to those aspects of my } \\
\text { course that require me to use Moodle }\end{array}$ & 0 & 0 & 0 & 0 & 2 & 7 & 16 & 53 & 12 & 40 & 4.33 \\
\hline $\begin{array}{l}\text { Moodle makes learning more } \\
\text { interesting }\end{array}$ & 0 & 0 & 0 & 0 & 3 & 10 & 21 & 70 & 6 & 20 & 4.1 \\
\hline $\begin{array}{l}\text { Learning with Moodle is innovative } \\
\text { approach to learning }\end{array}$ & & 0 & 0 & 0 & 3 & 10 & 17 & 57 & 10 & 33 & 4.23 \\
\hline I will use Moodle in the futu & & 0 & 0 & 0 & 2 & 7 & 14 & 47 & 14 & 47 & 4.4 \\
\hline $\begin{array}{l}\text { I will continue to use Moodle in the } \\
\text { other course units }\end{array}$ & 0 & 0 & 1 & 3 & 2 & 7 & 20 & 67 & 7 & 23 & 4.1 \\
\hline $\begin{array}{l}\text { I plan to use Moodle in my own } \\
\text { classes }\end{array}$ & 0 & 0 & 2 & 7 & 3 & 10 & 8 & 27 & 17 & 57 & 4.33 \\
\hline
\end{tabular}




\section{Discussion and Conclusion}

Moodle learning management system was highly accepted by a class of postgraduate students. All the students who used Moodle for software engineering and process modelling course had no experience in e-learning. The students' first interaction with Moodle gave them an opportunity to explore this new learning management system functionality. The students expressed satisfaction with online assessment system, ease of learning Moodle, online presentation of course materials, and the linkage between Moodle platform and individual email addresses. The University at present uses traditional lecture methods for teaching and learning with few departments using Google applications for uploading course materials and students' coursework results. There is clear advantage of adopting Moodle platform for teaching and learning as it has rich pedagogical tools and it is open-source software. Moodle can work effective in resource limited economies. However, for such a system to work well there is need for the University management to invest in the initial ICT infrastructure, that is, stable Internet connectivity and computer hardware equipment for learning management system implementation. There need to create technology-based teaching and learning awareness as some students were still reluctant to use Moodle learning environment at the beginning of the course, but they got motivated to use the system after interacting with it and using the learning tools.

The success of using Moodle platform for software engineering course implies that it can be effectively used for teaching other course in the University. More research is needed to find out effectiveness of using Moodle for teaching common courses to students across different universities in developing countries. In developing countries Universities do not have online collaborations. Open learning management system like Moodle provides opportunity to create a common class for postgraduate students to learn across Universities.

\section{References}

Alanso, F. (2005), "Instructional model for e-learning with a blended learning process approach," Br, J. Educ. Technol., vol. 36. No. 2, pp. 217-235, March. 2005. Ally, M., Anderson., M. and Elluomi, F. (2004). Eds., Foundations of Educational Theory for Online Learning. In Theory and Practice of Online Learning. Athabasca, AB, Canada: Athabasca Univ., 2004, pp. 3-29.

Bermejo, S. (2005). "Cooperative electronic learning in virtual laboratories through forums," IEEE Trans. Educ., vol. 48, no. 1, pp. 140-149, Feb. 2005.

Bersin, J. (2004). The Blended Learning Handbook. New York: Wiley, 2004.

Brandol, H. (1997). Web-based training cookbook, pp. 108.

Bullen, M, Pasian, B. L and Woodil, G, A. (2006). Eds., "When Worlds collide: Project management and the collegial culture." In Plan to Learn: Case Studies in e-Learning Project Management. Toronto, ON, Canada: CeLEA, 2006.

Communication from the Commission to the Council and the European Parliament: The Elearning Action Plan, European Commission, (March, 2011), Nov. 2007 [Online]. Available: lex.europa.eu/LexUriServ/site/en/com/2001/com2001/_0172en01.pdf.

Fletcher, J. D. (1991). Multimedia Review, spring 1991, pp. 33-42. 
Hirtz, S. (2008). Education for a Digital World. Advice, Guidelines, and Effective Practice from around the globe, D. G. Harper, Ed. Vancouver, BC, Canada: BC campus and Commonwealth of learning.

Johnson, S. D, Aragon, S. R, Egan, T. M and Lynham, S. A, (2002). Eds., An instructional strategy framework for online learning environments, In Proceedings of the Academy for Human Resource Development. Bowling Green, $\mathrm{OH}$ : Academy for Human Resource Development, 2002, pp. 1022-1029.

Jonassen, D. (1999). Constructivist learning environment on the web: Engaging students in meaningful learning, in Educational Technology Conference Exhibition.

Khalifa, M. and Lam, R. (2002). Web-based learning: Effects on learning process and outcome, IEEE transaction on Education, vol. 45, no. 4, pp. 350-356.

Knuth, R and Cunningham, D. (1993). Tools for constructivism. In T. M. Duffy, J. Lowyck, D. Jonassen, H. and Welsh, T. M. (1993). Designing Environments for constructivist learning, Eds. New York: Springer,1993, pp. 163-188.

Martin-Blas, T. and A. Serrano-Fernandez, A. (2009). The role of new technologies in the learning process: Moodle as a teaching tool in Physics, Computing Education, vol. 52, no. 1 , pp. 35-44.

Mishra, S. (2002). A design framework for online learning environments, Br. Journal of Educational Technology, vol. 33, no. 4. pp. 493-496.

MOODLE site, [online]. Available: http://moodle.org.

Morphew, V. N (2000). Web-based learning and instruction: a constructivist approach. In Distance Learning Technologies: Issues, Trends and Opportunities. L. Lau, Ed. Hershey, PA: Idea Group, 2000, pp. 1-15.

Nikolakaki, M. and Paraskeva, F. (2005). Integrating e-learning technologies and practices within university teaching: challenges and perspectives. Proceedings of the $5^{\text {th }}$ WSEAS International Conference on Applied Informatics and Communications, Malta, September, 15-17, 2005 (pp 138-142).

Romiszowski, A. J. (2004). How's the E-learning Baby? Factors Leading to Success or Failure of an Education Technology Innovation, Education Technology, pp. 5-48.

Tan, W., Lin, S., Yang, Y. and Zang, X. (2008). Design on collaborative virtual learning community and learning process visualization, Lecture notes on Computer science, vol. 5145, pp. 424-433.

Tanja, A., Matja, D., Matija, P., Borka, J. B. (2007). SUMI Evaluation of the EducaNext Educational Portal, Proceedings on the $7^{\text {th }}$ WSEAS International Conference on Applied Informatics and Communications, Athens, Greece, August 24-26, 2007.

Thorne, K. (2003). Blended learning. London, U.K.: Kogan Page, 2003.

Trenas, A. M., Ramos, J., Gutierrez, E. D., Romero, S., and Corbera, F. (2011). Use of a New Moodle module for improving the teaching of a basic course on Computer Architecture, IEEE transactions on Education, vol. 54. No. 2, pp. 222-228.

Vrasidas, C. (2004). Issues of Pedagogy and Design in e-learning Systems. SAC2004, March, 14-17, 2004, Nicosia, Cyprus.

Vrasidas, C., and Glass, G. V. (2002). A conceptual framework for studying distance education. In C. Vrasidas and G. V. Glass (Eds.), Current Perspectives in Applied Information Technologies: Distance Education and Distributed Learning, 31-56. Information Age Publishing, Inc., Greenwich, CT. 
Vrasidas, C. (2000). Constructivism versus objectivism: Implications for interaction, course design, and evaluation in distance education. International Journal of Educational Telecommunications, 6, (4), 339-362.

\section{Author Biography}

Bada Joseph Kizito holds a $\mathrm{PhD}$ from the Department of Computer Science and Statistics, Faculty of Science, University of Eastern Finland, Joensuu Campus, Finland. He is a member of ACM and IEEE. 